\title{
多環芳香族構造を有するエポキシ樹脂 Epoxy Resins Containing Polynuclear Aromatic Structure
}

梶 正 史*

Masashi KAJI

\section{1.はじめに}

エポキシ樹脂は，その良好な耐熱および耐湿性に加え， 機械的別よび電気的特性にも優れた特徵を有することから 工業的に広く利用されている。その一方, 近年の電気・電 子分野を中心とした用途における要求性能の高度化により 一層の高機能化が求められている。さらには, 環境負荷低 減の観点から, 非ハロゲン系での難燃性の向上屯強く求め られている。

これらの要求に対応させるべく, 高機能なエポキシ樹脂 の開発が活発に行われているが, その一例に多環芳香族構 造を有するエポキシ樹脂がある11。多環芳香族骨格の導入 は、その創直かつ疎水性に富んだ構造から耐熱性および耐 湿性の向上のための有力な手法であるとともに, その高い 熱安定性に起因して難燃性にあ優れた特徵があり, 非八口 ゲン難燃化のための有力な手法の一つである。

多環芳香族の代表例であるナフタレン構造を有するエポ キシ樹脂に関する研究としては，1-ナフトールとアルデ ヒド類との縮合により得られるノボラック構造のエポキシ 樹脂に関するむのがあり, 高耐熱性および低吸水性に優れ ることが報告されている22。また，越智らによる 1,6 -ジグ リシジルオキシナフタレンに関する研究があり，低熱膨張 性を示すことが報告されている3)。

また， 3 環以上の縮合多環芳香族構造を有する合成樹脂 に関する研究としては，大谷らによる研究例があり ${ }^{4)}$ ，加 熱時の高い残炭率から難燃性の向上が示唆されている。従っ て, 3 環以上の縮合多環芳香族骨格の導入は, 新たなエポ キシ樹脂設計の方向性を示すものとして興味深いが，その

* 新日鐵化学: (㑣) 機能材料事業本部 機能材料研究所 福岡県北九州市戸畑区中原先の浜 46-80 Nippon Steel Chemical Co., Ltd. Functional Materials Laboratories 46-80, Nakabaru, tobata, Kitakyusyu, Fukuoka 804-8503, Japan
構造と物性の関係に関しての研究例は未だ少ない。

一般的にグリシジルエーテル型のエポキシ樹脂は，図 1 の構造で表され，主骨格 A と連結基 B から構成されてい る。多環芳香族構造を有するエポキシ樹脂を得るためには, A， B 部位のそれぞれにビフェニル，ナフタレン，アント

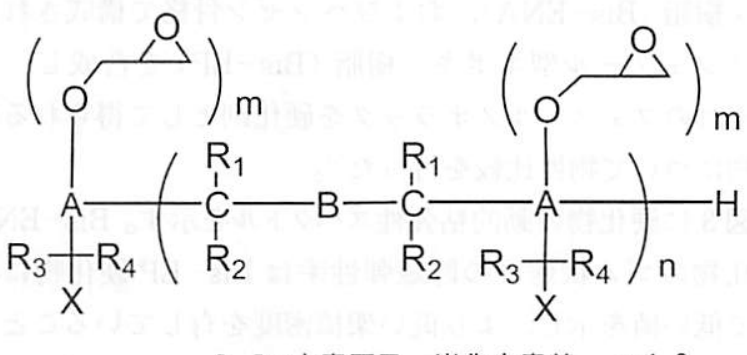
$R_{1}-R_{4}$ : 水素原子、炭化水素基 $m=1,2$ $n=1,2,3 \cdots$

A :
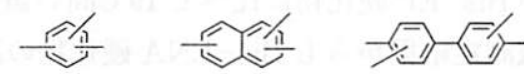

B :
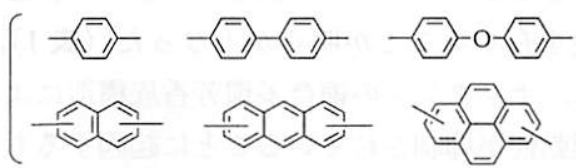

$\mathrm{x}$ :

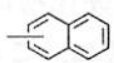

図 1 多環芳香族型エポキシ樹脂の構造

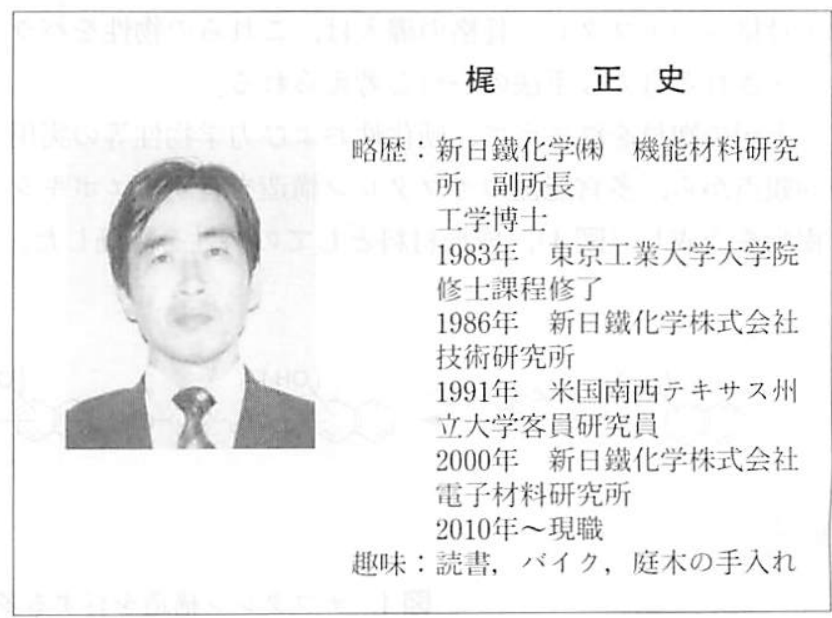


ラセン等の多環芳香族骨格を導入する方法がある。また, 主骨格 A に芳香族構造の置換基 X を導入する手法を取る こともできる。

さらには, 硬化剂側に同様の手法で多環芳香族構造を組 み入れ，エポキシ樹脂との硬化反応によってエポキシ樹脂 硬化物中に導入する方法がある。

ここでは, 2 環から 4 環の多環芳香族骨格の代表例とし て, ビフェニル, ジフェニルェーテル, ナフタレン, アン トラセンおよびピレン構造を有するエポキシ樹脂の合成例 之, それらから得られる硬化物の一般物性および寒用的観 点から無機フィラーを充填した系における成形材料として の成形性，機械物性および難燃性を中心とした熱的特性に ついて説明する。

\section{2. ナフタレン構造を有するエポキシ樹脂}

\section{1 主骨格へのナフタレン構造の導入}

主骨格へのナフタレン構造導入の効果を明らかにするた めに, 図 2 に示す新規なビスナフトール構造を有するエポ キシ樹脂 (Bis-ENA), およびベンゼン骨格で構成された ビスフェノール型エポキシ樹脂 $(\mathrm{Bis}-\mathrm{EP})$ を合成し，そ れぞれのフェノールノボラックを硬化剂として得られる硬 化物について物性比較を行った ${ }^{5}$ 。

図 3 に硬化物の動的粘弾性スペクトルを示す。Bis-ENA 硬化物のゴム状態での貯蔵弾性率は Bis-EP 硬化物に比 べて低い值を示し，より低い架橋密度を有していることを 示唆しているが, ガラス転移温度 $(T g)$ は Bis-ENA 硬化 物の方が Bis-EP 硬化物に比べて $19^{\circ} \mathrm{C}$ 高い值を示した。

熱機械測定結果からも Bis-ENA 硬化物の高 $T g$ 性が確 認されるととあに，ガラス状態书よびゴム状態ともに低熱 膨張性を有することが明らかとなった（表 1)。これらの 結果は, ナフタレンの縮合多環芳香族構造により, 分子主 鎖の運動性が抑制されていることに起因するあのと考えら れる。また, Bis-ENA 硬化物は, 高い破壊勒性と低吸水 性を示した（表 2)。一般に，これらの特性と Tg は相反関 係にあることが知られているが，そのなかでエポキシ樹脂 主骨格へのナフタレン骨格の導入は，これらの物性をバラ ンスされる有力な手法の一つ之考えられる。

上記の知見を踏まえて, 硬化性书よび力学物性等の実用 的観点から, 多官能性のナフタレン構造を有するエポキシ 樹脂を合成し（図 4), 成形材料としての特性を評価した。

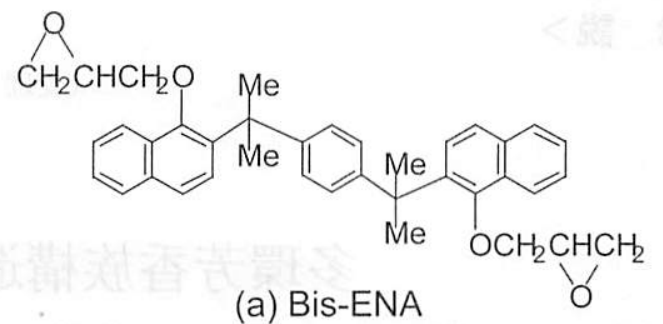

(a) Bis-ENA<smiles>CCOCCOc1ccc(C(C)(C)c2ccc(C(C)(C)c3ccc(OCCOC)cc3)cc2)cc1</smiles>

(b) Bis-EP

図 2 検討に用いたエポキシ化合物

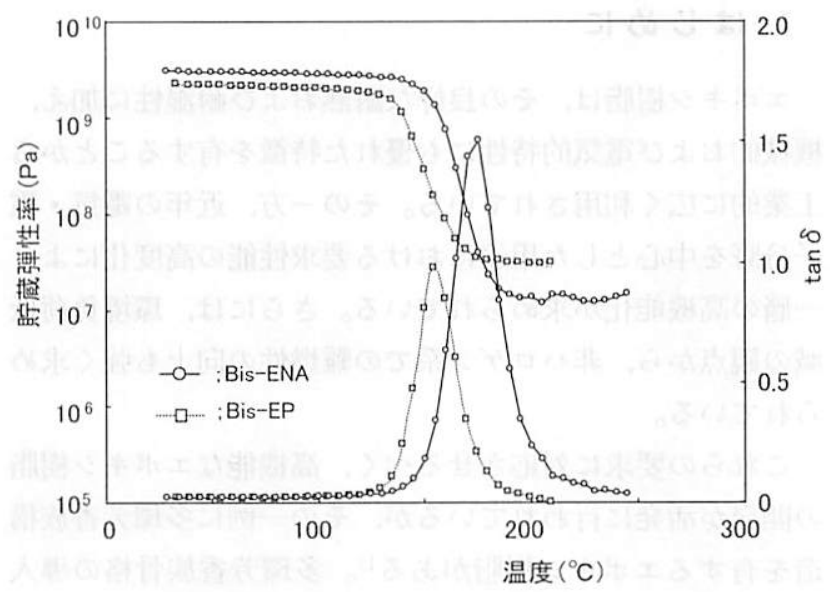

図 3 硬化物の動的粘弾性スペクトル

表 1 エポキシ樹脂硬化物の熱機械測定結果

\begin{tabular}{cccc}
\hline & & \multicolumn{2}{c}{$\mathrm{CTE}^{\mathrm{a})}\left(\times 10^{-5}{ }^{\circ} \mathrm{C}^{-1}\right)$} \\
\cline { 3 - 4 } エポキシ樹脂 & $T g\left({ }^{\circ} \mathrm{C}\right)$ & $<T g$ & $>T g$ \\
\hline Bis-ENA & 157 & 5.0 & 16.4 \\
Bis-EP & 131 & 6.4 & 17.4 \\
\hline
\end{tabular}

a) Coefficient of linear thermal expansion

表 2 エポキシ樹脂硬化物の物性

\begin{tabular}{lcccc} 
エポキシ樹脂 & $\begin{array}{c}\text { 曲げ強度 } \\
(\mathrm{MPa})\end{array}$ & $\begin{array}{c}\text { 曲げ弾性率 } \\
(\mathrm{GPa})\end{array}$ & $\begin{array}{c}\text { 破壊勒性 } \\
\left(\mathrm{MPa} \cdot \mathrm{m}^{1 / 2}\right)\end{array}$ & $\begin{array}{c}\text { 吸水率 } \\
(\mathrm{wt} \%)\end{array}$ \\
\hline Bis-ENA & 88 & 3.86 & 0.99 & 1.27 \\
Bis-EP & 118 & 2.89 & 0.98 & 1.63 \\
Bis-EA $^{\text {b) }}$ & 115 & 3.09 & 0.76 & 1.96 \\
\hline
\end{tabular}

a) $133^{\circ} \mathrm{C}, 3 \mathrm{~atm}, 96 \mathrm{~h}$

b)ピスフェノール A 型エポキシ樹脂

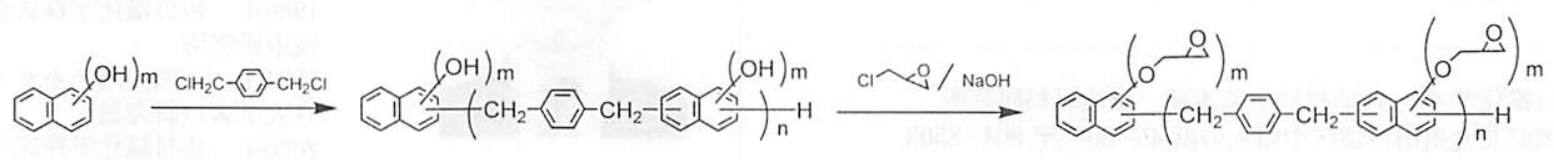

図 4 ナフタレン構造を有する多官能性エポキシ樹脂の合成スキーム 
表 3 無機フィラー充填系におけるエポキシ樹脂硬化物の物性

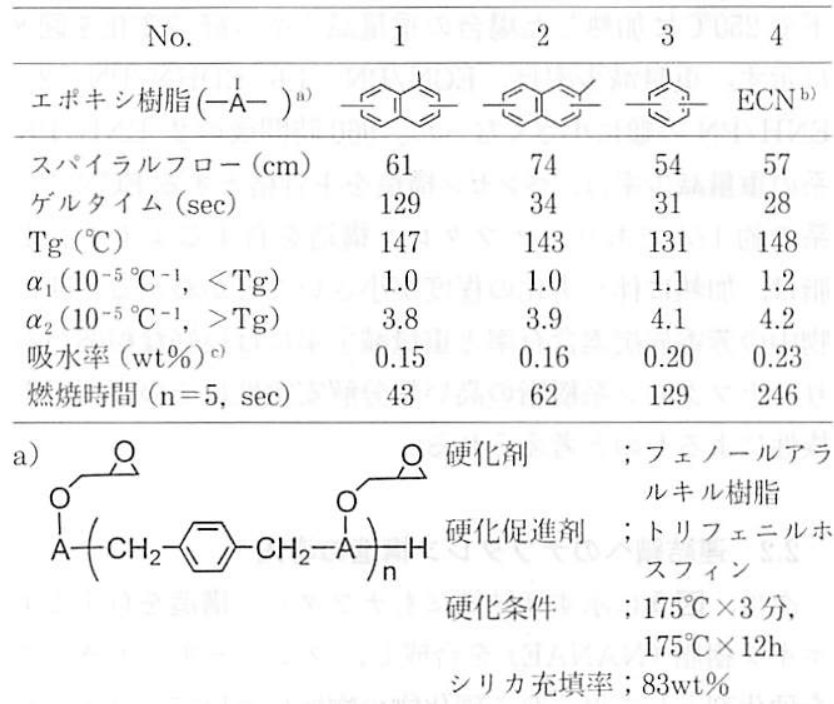

b）。ークレゾールノボラック型エ ポキシ樹脂

c) $85^{\circ} \mathrm{C}, 85 \%, 100 \mathrm{~h}$

表 3 にフェノールノボラックを硬化刘として用いた場合 の成形材料としての評価結果を示す。1-ナフトールから 誘導されるエポキシ樹脂 (No. 1)，2-ナフトールからの樹 脂 (No. 2) とすに多官能性とすることで, 良好な成形性を 有することで実績のある既存のエポキシ樹脂 (ECN) と同 等の硬化性と流動性を示した。また, 二官能性のモデル化 合物で確認されたとおり, ナフタレン構造を導入すること による高耐熱性, 低吸湿性および低熱膨張性の効果が認め られた。さらに，既存の ECN およびフェノール骨格をべー スとしたエポキシ樹脂 (No. 3) に比べて, 大幅な難燃性の 向上が確認された。燃焼時間とエポキシ樹脂組成物中のエ ポキシ基濃度には高い相関があることがわかっており，ナ フタレン構造を有するエポキシ樹脂の高い難燃性は, ナフ タレン構造の導入により, 結果として易燃性のエポキシ部 位濃度の低減が大きく寄与しているものと考えることがで きる。

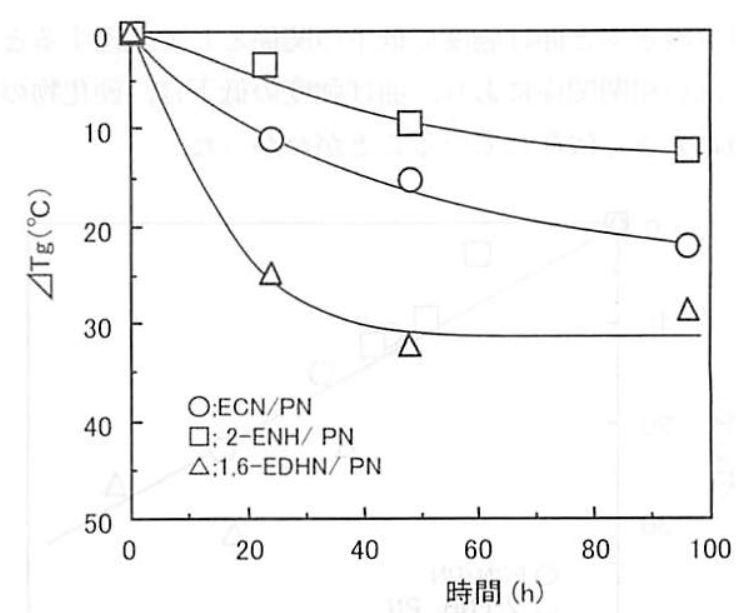

図 5 吸水時間と $T g$ 低下幅の関係 吸水条件 ; $85^{\circ} \mathrm{C}, 85 \%$ R. H.

次に，表 4 のエポキシ樹脂および硬化剤の組み合わせに より得られる 9 種類の硬化物について, 吸湿および高温加 熱後の硬化物物性への影響について調べた。

図 5 に硬化剂に PN を用いて得られる硬化物の $T g$ の低 下温度の経時変化を示す。一般に，高分子の $T g$ は水分子 の可塑化効果により，吸水量に応じて低下することが良く 知られている ${ }^{6)}$ 。ここであ，硬化物の $T g$ は吸水とともに 低下することが確認され，特に $200^{\circ} \mathrm{C}$ 以上の高 $\mathrm{Tg}$ 性を示 した 1,6-EDHN/PN 系においては，最大 $30^{\circ} \mathrm{C}$ の低下が認 められた。一方，吸水率の小さい2- $\mathrm{ENH} / \mathrm{PN}$ 系は，吸 水に伴う $T g$ の低下が小さく $10^{\circ} \mathrm{C}$ 程度の低下に留まった。

この結果を吸水率と $T g$ の低下幅との関係で整理すると, 吸水率之 $T g$ の低下割合に良好な相関関係が認められた (図 6)。なお，硬化物を再度乾燥をすることにより，Tg は完全に回復することが確認されており, $T g$ の低下は吸 湿された水による可塑化効果に基づくものと考えられる。

次に, 力学物性への影響について調べた。炭素織維複合 材料の研究において, 吸水量の増大とともに剪断強度が低 下するとの報告がある7)。本研究においても, 硬化物の曲 げ強度は吸水とともに低下することが確認された（図 7)。

表 4 検討に用いたエポキシ樹脂および硬化剂

No.


これを吸水率と曲げ強度の低下の関係として整理すると両 者は高い相関関係にあり, 曲げ強度の低下は, 硬化物の吸 水量に大きく依存していることがわかった。

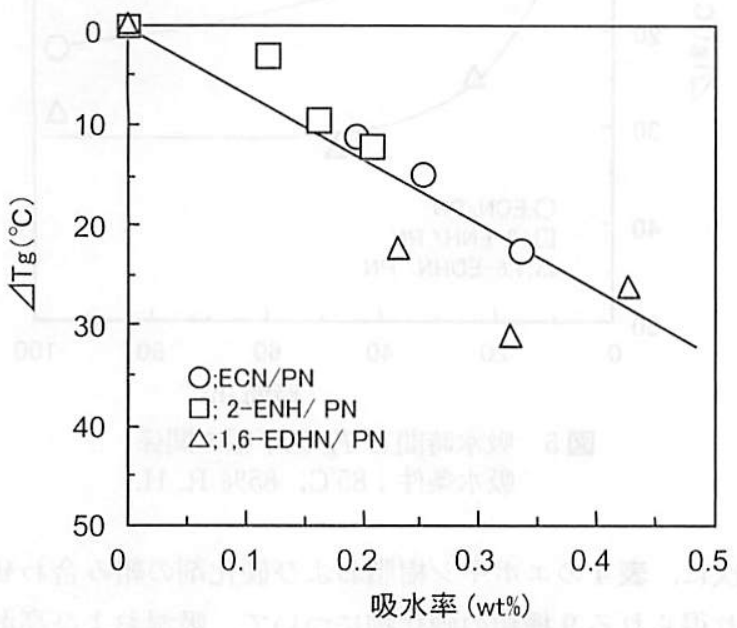

図 6 吸水率之 $T g$ 低下幅の関係 吸水条件 ; $85^{\circ} \mathrm{C}, 85 \%$ R. H.

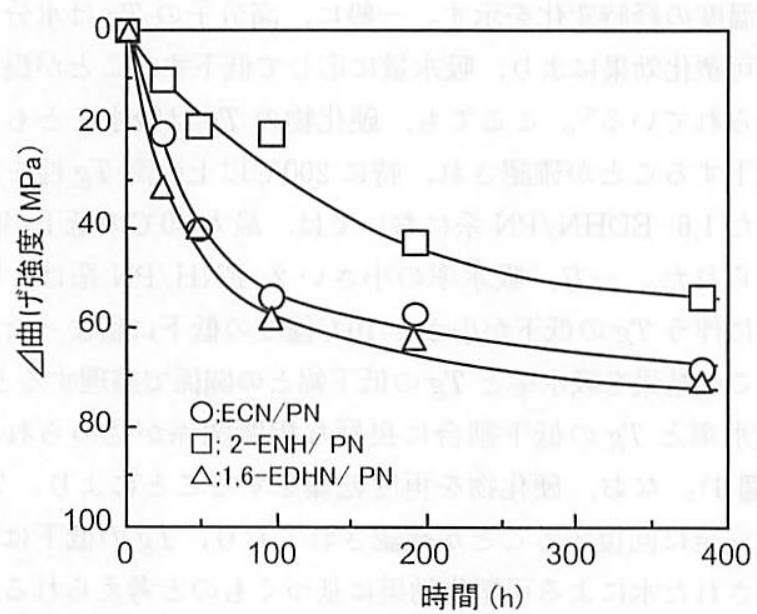

図 7 吸水時間と曲げ強度低下幅の関係 吸水条件 ; $85^{\circ} \mathrm{C}, 85 \%$ R. H.

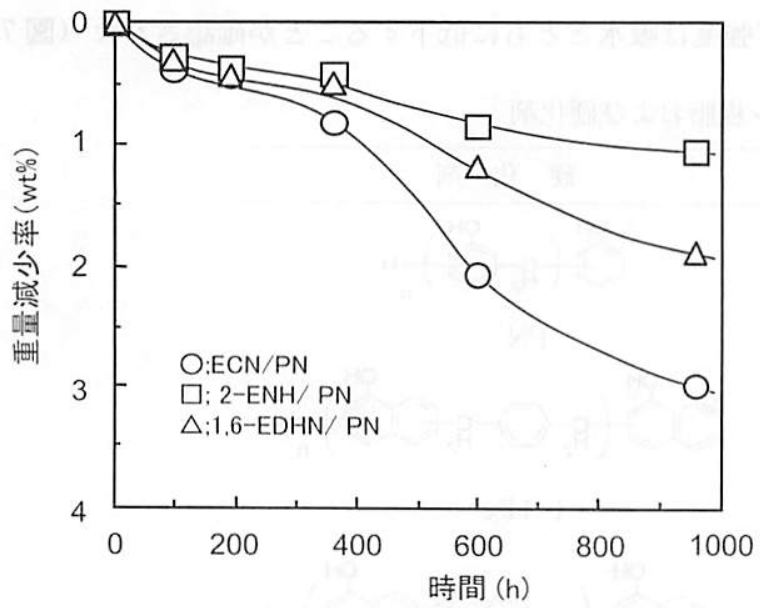

図 8 加熱時間之重量減少率の関係 加熱条件； $250^{\circ} \mathrm{C}$ シリカ充填率； $75 \mathrm{wt} \%$
PN を硬化剂として得られた硬化物について, 酸素存在 下で $250^{\circ} \mathrm{C}$ に加熱した場合の重量減少率の経時変化を図 8 に示す。重量減少率は, ECN/PN $>1,6-\mathrm{EDHN} / \mathrm{PN}>2-$ $\mathrm{ENH} / \mathrm{PN}$ の順に小さくなった。9 900 時間後の 2-ENH/PN 系の重量減少率は, ベンゼン構造を主骨格とする ECN/PN 系の約 $1 / 3$ であり，ナフタレン構造を有するエポキシ樹 脂は, 加熱に伴う劣化の程度が小さいことがわかる。硬化 物中の芳香族炭素含有率之重量減少率には良好な相関があ り,ナフタレン系樹脂の高い熱分解安定性はその高い芳香 族性によるものと考えられる。

\section{2 連結鎖へのナフタレン構造の導入 ${ }^{87}$}

次に, 図 9 に示す連結鎖にもナフタレン構造を有するエ ポキシ樹脂 (NANAE) を合成し，フェノールノボラック を硬化剂として得られる硬化物の物性について, フェニレ ン構造を連結鎖に持つナフトール系エポキシ樹脂 (NAE) およびフェノール系エポキシ樹脂 (PAE) の硬化物の物性 を比較検討した。

図 10 に NANAE, NAE およびPAEをフェノールノボ ラックで硬化させて得られる硬化物の動的粘弾性测定結 果を示す。ゴム状態での貯蔵弾性率は, PAE $>\mathrm{NAE}>$ NANAEの順で小さい值となった。これは，エポキシ当

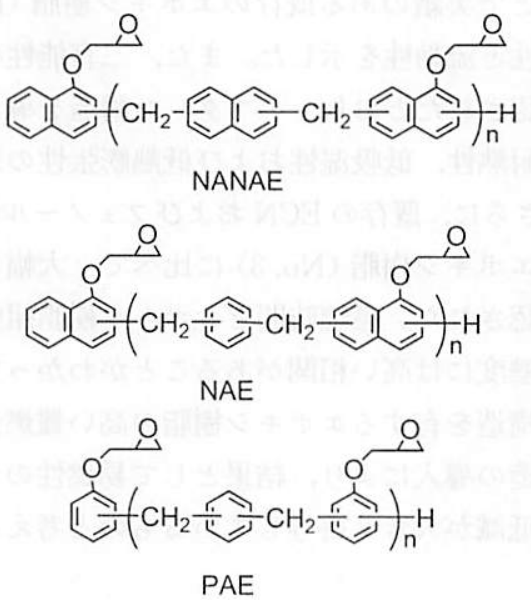

図 9 検討に用いたアラルキル型エポキシ樹脂

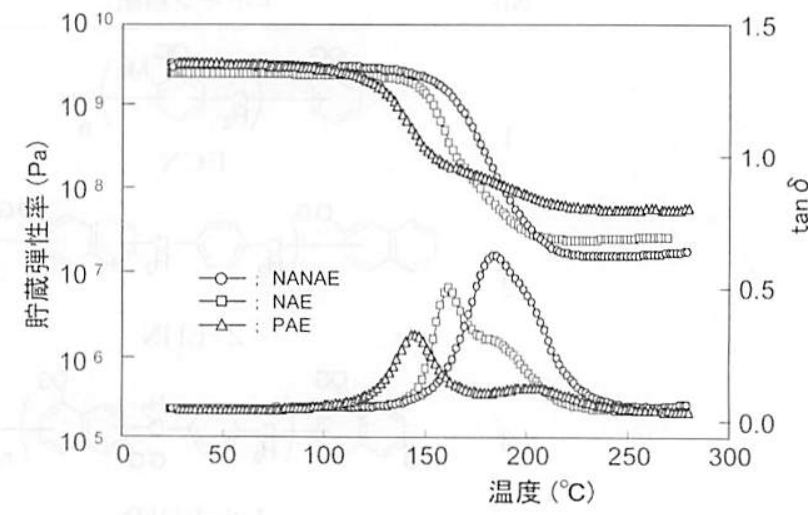

図 10 硬化物の動的粘弾性スペクトル 
量から見積もられるエポキシ樹脂硬化中のエポキシ基由来 部位の濃度に対応しており, 硬化物の架橋密度もこの順で 低下しているむのと考えられる。一方, $\tan \delta$ のピーク温 度から読み取った Tg は, NANAE, NAEおよびPAEの

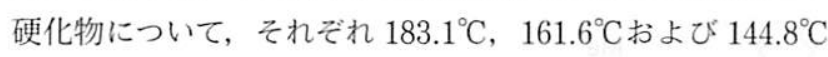
であり, 架橋密度とは逆に NANAE $>$ NAE $>$ PAE の順で 高い值を示した。主骨格および連結基とむにベンゼン構造 を持っPAEに対して, 主骨格にナフタレン構造を有する $\mathrm{NAR}$ は, $16.8^{\circ} \mathrm{C}$ 高い值となり, さらに連結基にあナフタ レン構造を導入することにより, NAEに対してNANAE の $\mathrm{Tg}$ は $21.5^{\circ} \mathrm{C}$ 高くなった。これらの挙動は, 縮合多環芳 香族構造であるナフタレン環の剛直性に基づく分子運動の 抑制作用が大きく奇与しているすのと考えられる。以上の 結果から, 連結基にナフタレン構造を導入することは, 主 骨格にナフタレン構造を導入することと同等以上の $T g$ の 向上効果があることが示された。

表 5 に熱機械测定結果を示す。動的粘弾性測定の結果 と同様に Tg は, NANAE > NAE > PAE の順であり, NANAE 硬化物は $170.6^{\circ} \mathrm{C}$ と最も高い值を示した。一方, ガラス状態における熱膨張率は, 主骨格および連結基とも にナフタレン骨格を持つNANAEが最む小さい值を示し, $\mathrm{PAE}>\mathrm{NAE}>\mathrm{NANAE}$ の順であった。金城らは ゾールノボラック型エポキシ樹脂硬化物に関する研究にお いて, ガラス状態の熱膨張率は架橋密度とともに上昇する ことが明らかにし，これは架橋点による分子パッキング阻 害に基づく分子鎖間の van der Waals 力の低下に起因す るものと考察している ${ }^{9)}$ 。本研究において架橋密度はPAE $>\mathrm{NAE}>\mathrm{NANAE}$ の順で低下することから, NANAEの 低熱膨張性は架橋点による分子鎖のパッキング阻害の抑制 がその一因と考えることができる。

一方, 筆者らはこれまでの検討において, ナフタレン系 エポキシ樹脂においてもガラス状態の熱膨張率は架橋密度 とともに上昇するが, 同じ架橋密度で比較した場合, ナフ タレン系エポキシ樹脂はベンゼン系エポキシ樹脂に比べて 低熱膨張性を示すことを確認している10)。本検討における 熱膨張率の序列 $\mathrm{PAE}>\mathrm{NAE}>\mathrm{NANAE}$ は, エポキシ樹脂 中のナフタレン環の含有率と逆の関係にあることから, NANAEの低熱膨張性はナフタレンの縮合多環芳香族構 造に基づく分子振動の抑制が大きく影響しているものと考

表 5 エポキシ樹脂硬化物の熱機械測定結果

\begin{tabular}{cccc}
\hline & & \multicolumn{2}{c}{$\mathrm{CTE}^{\mathrm{a})}\left(\times 10^{-5} \mathrm{C}^{-1}\right)$} \\
\cline { 3 - 4 } エポキシ樹脂 & $\operatorname{Tg}_{\text {-TMA }}\left({ }^{\circ} \mathrm{C}\right)$ & $\langle\mathrm{Tg}$ & $>\mathrm{Tg}$ \\
\hline NANAE & 170.6 & 4.9 & 16.9 \\
NAE & 146.4 & 5.2 & 16.5 \\
PAE & 136.5 & 6.3 & 16.9 \\
\hline
\end{tabular}

a) Coefficient of linear thermal expansion
表 6 無機フィラー充填系におけるエポキシ樹脂硬化物の物性

\begin{tabular}{lccc}
\hline \multicolumn{1}{c}{ No. } & NANAE & NAE & PAE \\
\hline スパイラルフロー $(\mathrm{cm})$ & 32 & 34 & 41 \\
ゲルタイム $(\mathrm{sec})$ & 31 & 33 & 30 \\
$\operatorname{Tg}\left({ }^{\circ} \mathrm{C}\right)$ & 152 & 133 & 126 \\
$\alpha_{1}\left(10^{-5}{ }^{\circ} \mathrm{C}^{-1},<\mathrm{Tg}\right)$ & 0.9 & 1.0 & 1.1 \\
$\alpha_{2}\left(10^{-5}{ }^{\circ} \mathrm{C}^{-1},>\mathrm{Tg}\right)$ & 5.0 & 4.9 & 5.2 \\
曲げ強度 $\left(\mathrm{MPa}, 25^{\circ} \mathrm{C}\right)$ & 145 & 152 & 150 \\
曲け弾性率 $\left(\mathrm{GPa}, 25^{\circ} \mathrm{C}\right)$ & 26 & 25 & 24 \\
曲げ強度 $\left(\mathrm{MPa}, 240^{\circ} \mathrm{C}\right)$ & 16 & 18 & 22 \\
曲け弾性率 $\left(\mathrm{GPa}, 240^{\circ} \mathrm{C}\right)$ & 0.25 & 0.34 & 0.85 \\
吸水率 $\left(\mathrm{wt} \%, 85^{\circ} \mathrm{C}, 85 \% \mathrm{RH}, 100 \mathrm{~h}\right)$ & 0.15 & 0.17 & 0.21 \\
燃焼時間 $(\mathrm{sec}, \mathrm{n}=5)$ & 28 & 64 & 196 \\
重量保持率 $\left(\mathrm{wt} \%, 250^{\circ} \mathrm{C}, 1000 \mathrm{~h}\right)$ & 96.0 & 94.0 & 94.5 \\
\hline
\end{tabular}
シリカ充填率 ; $83 \mathrm{wt} \%$
硬化促進剤 $\quad ;$ トリフェニルホスフィン
硬化刘 $\quad$ ）フェノールアラルキル樹脂

えられる。

表 6 にシリカを $83 \mathrm{wt} \%$ 充填した系における成形材料と しての評価結果を示す。

成形材料においても, NANAE 硬化物の高い $T g$ と低 熱膨張性が確認された。また吸水率は, PAE $>\mathrm{NAE}>$ NANAEの順に小さい值を示した。一般的傾向として, エポキシ樹脂硬化物は $\operatorname{Tg}$ が高くなるとともに吸水率も上 昇し，耐熱性と耐湿性は相反する関係にあることが報告 されている ${ }^{9)}$ 。これは架橋密度の上昇に伴い Tg が高く なる一方, 架橋点による分子鎖のパッキング阻害により 自由空間体積が大きくなることに加えて，エポキシ基の 開環に伴う水酸基の濃度が高くなるために吸水率が上昇す るものと考えられている。本検討では, TgはNANAE> NAE $>$ PAE の順であり, NANAE は高 $T g$ 性を発揮し つつ低吸水性を達成できる方向にあることがわかる。これ は，主骨格に加えて連結鎖にむナフタレン骨格を導入した ことによる高いナフタレン骨格含有率によるあのと考えら れる。

表中の重量保持率は, $250^{\circ} \mathrm{C}$ 熱風オーブン中で 1,000 時間保持した後の樹脂成分に換算した值を示している。通 常の o-クレゾールノボラック型エポキシ樹脂の重量保持 率は $91 \mathrm{wt} \%$ 程度であり, 本検討に用いたアラルキル型エ ポキシ樹脂の重量保持率は全体的に高い傾向にあるが, な かでも NANAE 硬化物は，96.0wt\%と高い重量保持率を 示しており熱分解安定性にも優れることがわかる。また， 燃焼時間は UL-94 試験における 5 本の試験片の合計燃焼 時間を表しているが, NANAE 硬化物の高い熱分解安定 性に対応して，良好な難燃性を示した。

また， NANAE 硬化物は高温 $\left(240^{\circ} \mathrm{C}\right)$ 時において低い 曲げ弾性率を示すことが確認された。これは, 図 9 の動的 粘弾性スペクトルの結果にも対応しており, NANAE 硬 化物の低い架橋密度よるものと考えられる。 


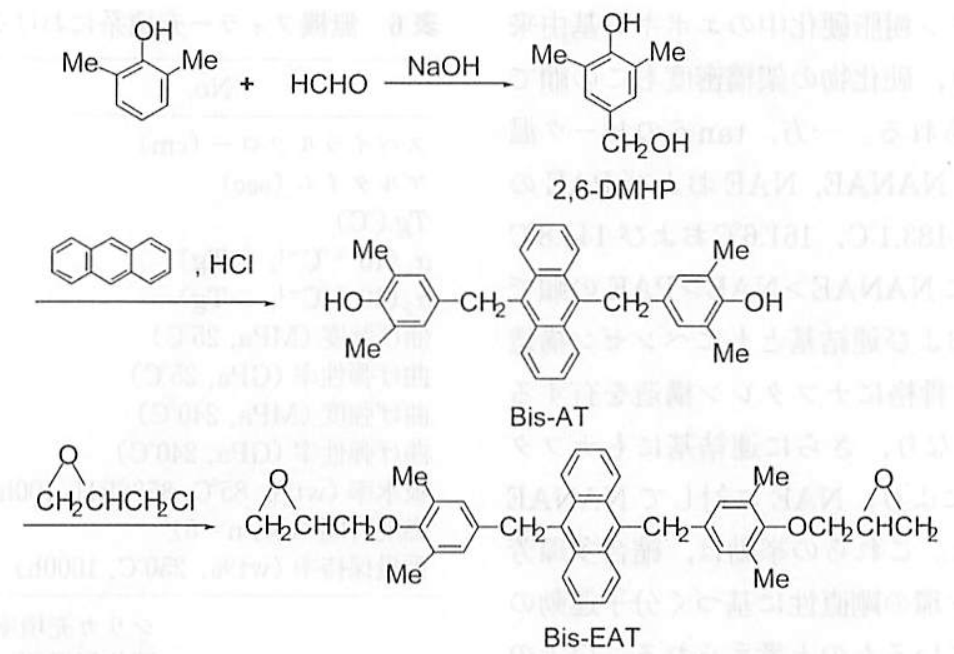

図 11 アントラセン構造を有するエポキシ樹脂の合成ルート

\section{3. 連結鎖へのアントラセン構造の導入 ${ }^{11}$}

3 環の縮合多環芳香族化合物の代表例として, アントラ セン構造を有するエポキシ樹脂を合成するとともに（図 11)，アントラセンユニットをベンゼン骨格で置換した Bis -EBZ（図 12）を合成し，フェノールノボラックを硬化剤 として得られる硬化物の物性を比較した。

図 13 に Bis-EAT と Ris-FR7 の硬化物の動的数就性 スペクトルを示す。Bis-EAT 硬化物のゴム状態での低い 平衡弾性率から, Bis-EAT 硬化物の方が低架橋密度を有 すると考えられるが, $\tan \delta$ のピーク温度から読み取った $\mathrm{Tg}$ は Bis-EBZ 硬化物に比べて $26^{\circ} \mathrm{C}$ 高い値となった。

Bis-EAT 硬化物の高 $T g$ 性は, アントラセンの縮合多 環芳香族構造により分子の運動が抑制されているためと考 えられる。さらに，9,10-アントラセン基の立体的な高高 さむ分子運動の抑制に作用し， $T g$ 上昇に寄与しているも

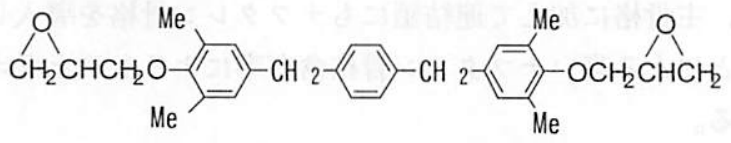

図 12 Bis-EBZ の構造

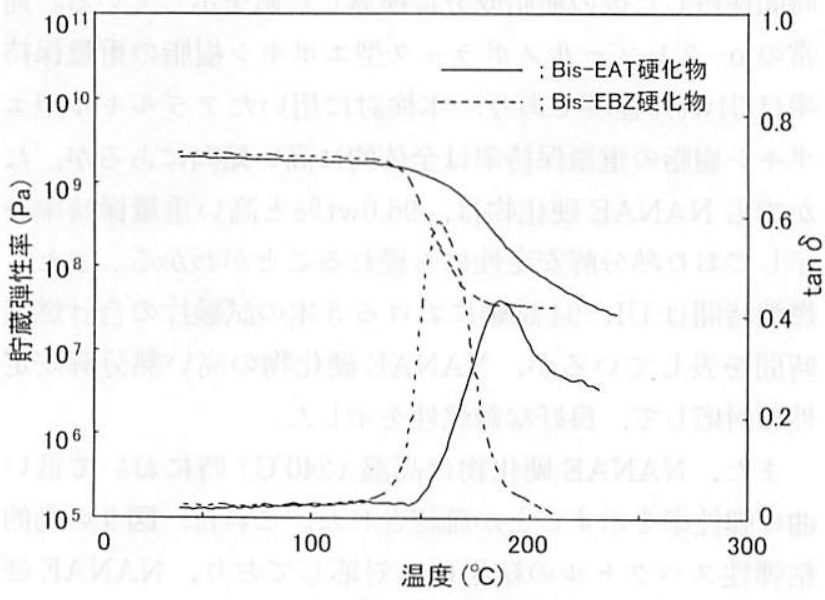

図 13 エポキシ樹脂硬化物の動的粘弾性スペクトル
のと推察した。

表 7 にそれぞれの硬化物の熱機械測定結果を示すが, これからも Bis-EAT 硬化物の高 $T g$ 性が確認されると ともに，Bis-EAT 硬化物の低熱膨張性が認められた。特 に, Bis-EAT 硬化物のゴム状態での線膨張係数は $12.7 \times$ $10^{-5}{ }^{\circ} \mathrm{C}^{-1}$ 之極めて小さい值を示した。これはナフタレン 構造を有するエポキシ樹脂における值と比較しても，大幅

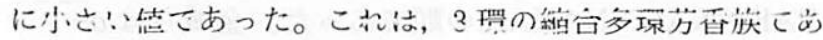
るアントラセン構造の導入により，分子運動が大きく抑制 されたことによるむのと考えられる。

図 14 に硬化物の窒素気流下での示差熱重量測定結果を 示す。Bis-EAT 硬化物の $700^{\circ} \mathrm{C}$ での残炭率は $32 \mathrm{wt} \%$ あ

表 7 硬化物の熱機械測定結果

\begin{tabular}{cccc}
\hline & & \multicolumn{2}{c}{$\mathrm{CTE}^{\mathrm{a})}\left(\times 10^{-5}{ }^{\circ} \mathrm{C}^{-1}\right)$} \\
\cline { 3 - 4 } エポキシ樹脂 & $\operatorname{Tg}\left({ }^{\circ} \mathrm{C}\right)$ & $<T g$ & $>T g$ \\
\hline Bis-EAT & 151 & 5.8 & 12.7 \\
Bis-EBZ & 135 & 6.2 & 17.4 \\
\hline
\end{tabular}

a) Coefficient of linear thermal expansion

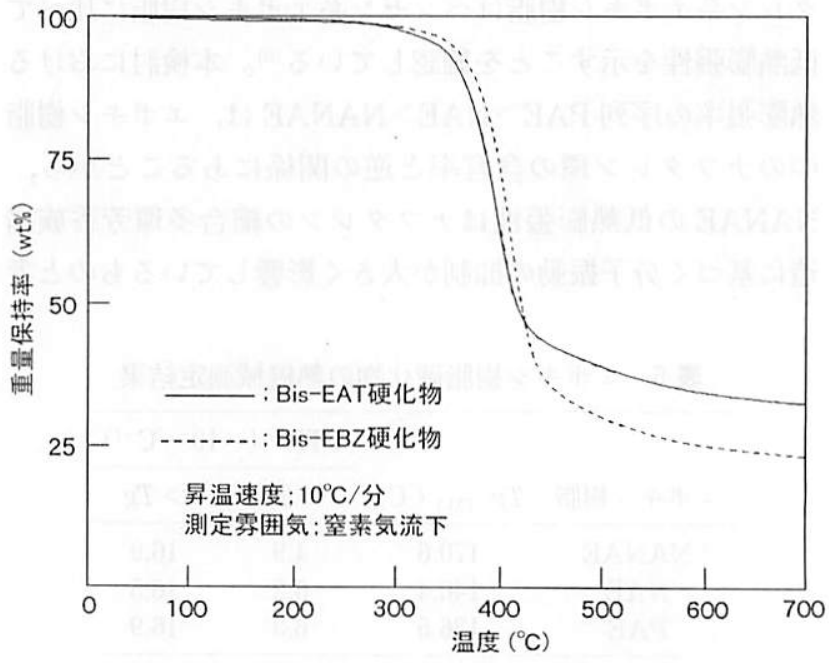

図 14 エポキシ樹脂硬化物の熱重量曲線 
り，Bis-EBZ 硬化物に比べて大幅に高い值を取った。ア ントラセン構造の高い芳香族性に基づくあのと考えられる。 一方, $10 \mathrm{wt} \%$ 重量減時の温度 $\left(T_{10 \%}\right)$ は, Bis-EBZ 硬化 物に比べて $7{ }^{\circ} \mathrm{C}$ 低い值となったが，これは反応性の高いア ントラセンの 9,10 -位での結合解離によるものと推察し ている。

\section{4. 連結鎖へのピレン構造の導入 ${ }^{12}$}

次に，4環の縮合多環芳香族としてピレンを取り上げ， 新規なピレン構造を有するエポキシ樹脂 (PGEPY) を合成 し（図 15），フェノールノボラックを硬化剤として得られ る硬化物の物性を評価した。合わせて，ピレンユニットを アントラセンユニットで置換したエポキシ樹脂 (PGEAT) およびビスフェノール A 型エポキシ樹脂 (Bis-EA)につ いても物性評価を行った。

表 8 に熱機械測定結果を示す。Bis-EA, PGEAT およ び PGEPY のエポキシ当量（186，297 および $304 \mathrm{~g} /$ eq.) から判断して, PGEPY が最む低い架橋密度を有すること が予測されるが, PGEPY 硬化物が最む高い Tg を示した。 これは，ピレンの 4 環の縮合多環芳香族構造に起因した分 子運動の抑制に加えて，ピレン骨格の嵩高さにより分子主 鎖の運動が抑制されているためと思われる。また，線膨張 係数も PGEPY が最む小さい值を取ったが，縮合多環芳 香族構造に基づく分子運動の抑制が反映したものと考えら れる。

また，図 16 に硬化物の咥素気流下での示差熱重量測定 結果を示す。PGEPY 硬化物の $700^{\circ} \mathrm{C} て ゙ の$ 残炭率は $37 \mathrm{wt} \%$ であり，その高い芳香族性に起因して極めて高い值となっ た。アントラセン構造を持つ PGEAT 硬化物む, $700^{\circ} \mathrm{C} て ゙$ の残炭率は $31 \mathrm{wt} \%$ と比較的高い值を示したが，分解開始

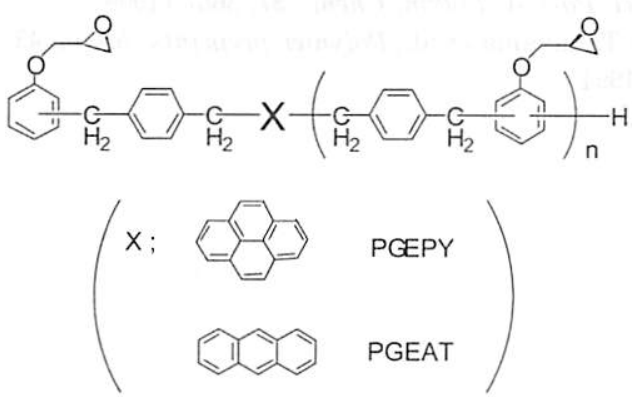

図 15 多環芳香族構造を有するエポキシ樹脂の構造

表 8 エポキシ樹脂硬化物の熱機械測定結果

\begin{tabular}{cccc}
\hline & & \multicolumn{2}{c}{$\mathrm{CTE}^{\mathrm{a})}\left(\times 10^{-5}{ }^{\circ} \mathrm{C}^{-1}\right)$} \\
\cline { 3 - 4 } エポキシ樹脂 & $\operatorname{Tg}\left({ }^{\circ} \mathrm{C}\right)$ & $<\mathrm{Tg}$ & $>\mathrm{Tg}$ \\
\hline PGEPY & 137 & 5.6 & 15.4 \\
PGEAT & 134 & 5.8 & 15.5 \\
Bis-EA & 132 & 6.2 & 17.8 \\
\hline
\end{tabular}

a) Coefficient of linear thermal expansion

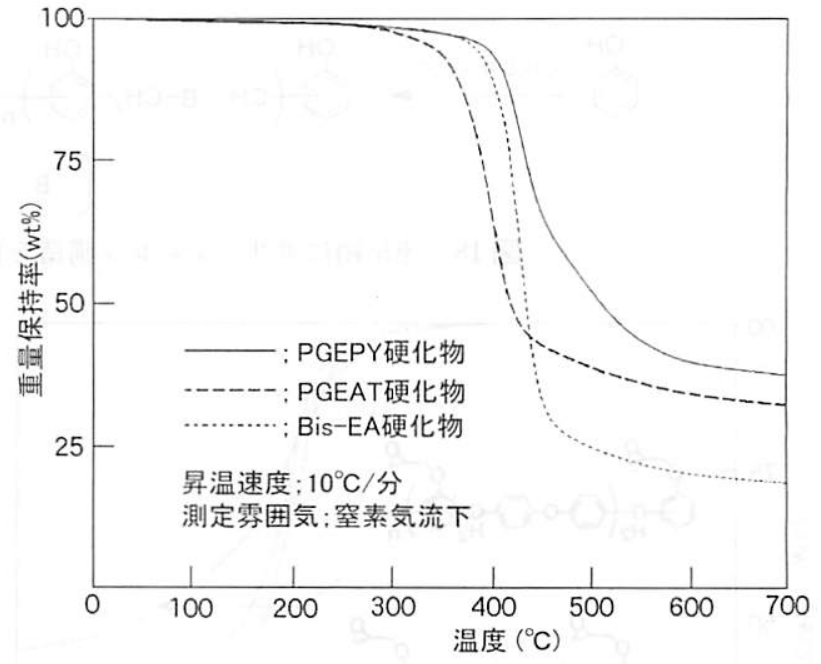

図 16 エポキシ樹脂硬化物の熱重量曲線

温度は前項の連結鎖にアントラセン構造を持つエポキシ樹 脂硬化物と同様に低い值となった。アントラセンは $9,10-$ 位の電子密度が高いため, エポキシ樹脂前駆体は比較的容 易にこの位置で反応し合成される一方, 解離反応屯置きや すくなっているためと考えている。

\section{5. 連結鎖へのポリフェニレン構造の導入}

次に，連結鎖中へ立体障害が小さく直線性の高いポリフェ ニレン基の導入を試みた。まず，ビフェニレン基導入の効 果を検証するため, 図 17 に示すモデル化合物を合成し, 硬化物の物性を評価した。剛直なビフェニレン基の導入に より, 耐熱性, 耐湿性の向上に加え, 架橋点間距離が長く なることで勒性の向上にも大きく寄与することを明らかに した ${ }^{13)}$ 。

上記の知見をむとに, 実用的観点から多官能性のエポキ シ樹脂を合成し，硬化物の物性を評価した（図 18）。

図 19 にフェノールノボラックを硬化剤として得られる エポキシ樹脂硬化物の示差熱重量分析結果を示す。

ジフェニルエーテル構造を有するエポキシ樹脂硬化物の 場合，窒素気流下， $700^{\circ} \mathrm{C}$ における残炭率は $44.0 \mathrm{wt} \%$ た り，他の樹脂系に比べて特異的に高い值を示した ${ }^{14)}$ 。高 山らにより，ポリフェニレンェーテル等の酸素原子を含有

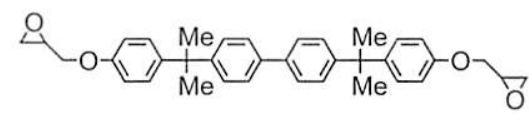

(a)Bis-EBP

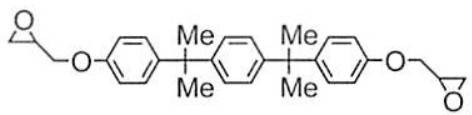

(b)Bis-EP

図 17 モデルエポキシ化合物の構造 


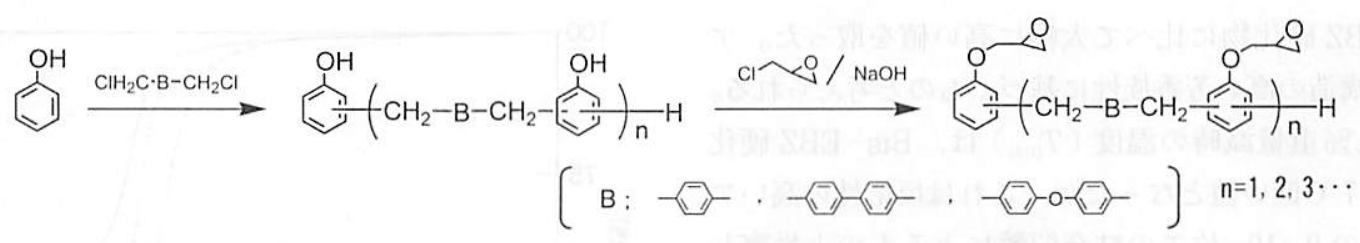

図 18 連結鎖にポリフェニレン構造を有する多官能性エポキシ樹脂の合成スキーム

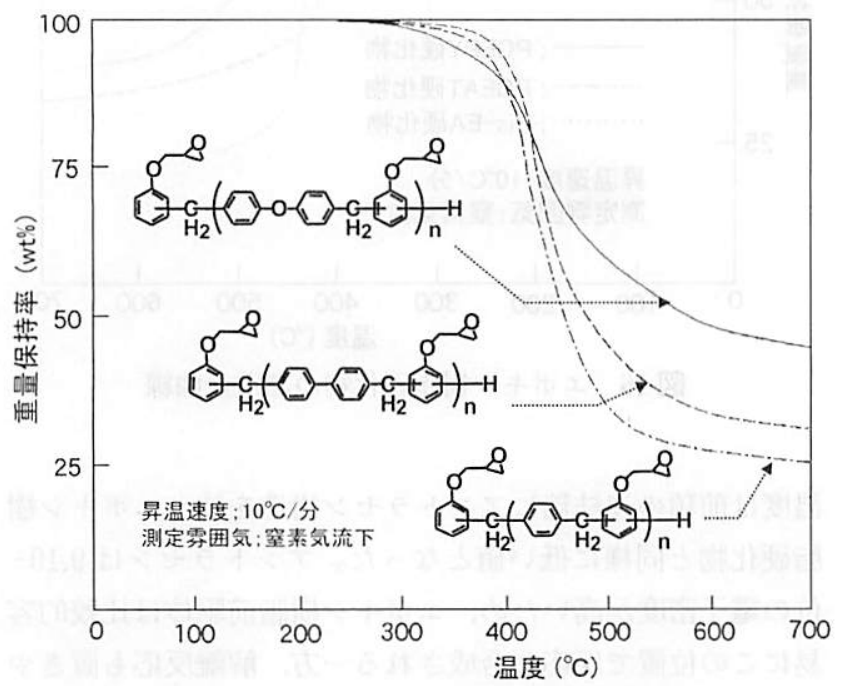

図 19 エポキシ樹脂硬化物の熱重量曲線

する芳香族系高分子が高い残炭率を有することが報告され， これは高分子鎖の芳香族ユニット間の縮合による多環芳香 族化が進行することによるあのと考えられている ${ }^{15)}$ 。本系 においても, ジフェニルェーテル構造の導入により多環芳 香族化が進行し炭化が促進されるためと推察している。

\section{6. おわりに}

エポキシ樹脂構造中への多環芳香族骨格の導入は，耐熱 性，耐湿性および低熱膨張性の向上に有効であるとともに， その高い芳香族性に起因して難燃性の向上にも効果がある ことが示された。さらには，高 $T g$ 性に代表される物理的 耐熱性だけではなく，熱分解安定性に代表される化学的耐
熱性の向上にも有効であることが示された。多環芳香族構 造の導入は，新たな樹脂設計の方向性を示するのとして興 味深い。一方，ここではあまり触れなかったが，硬化反応 性, 溶剤溶解性等の作業性む実用面からは極めて重要な要 素であり，これらを考慮した分子設計が今後の課題である。

\section{参 考 文 献}

1）梶正史，日本接着学会誌，38, 262 (2002)

2）特開炤 59-230017 号

3）越智光一, 怦井卓己, 景山洋行, 新保正樹, 日本接着学会誌, 25, 222 (1989)

4）特開昭 $62-521$ 号

5) M. Kaji, K. Ogami, and T. Endo, J. Appl. Polym. Sci., 72, 953 (1999)

6) A. Wereta, J. A. Bailie, J. Boeddiker, and R. L. Cothern, National SAMPE Tech. Conf. Adv. Mater. Process Eng., 13, 310 (1981)

7) O. Gillat and L. J. Groutman, ASTM STP 658, 61 (1978)

8）福永智美, 大神浩一郎, 中原和彦, 梶正史, 遠藤剛, ネット ワークポリマー, 30, 142 (2009)

9) N. Kinjo, M. Ogata, K. Nishi, and A. Kaneda, Advances in Polymer Science, 88, 1 (1989)

10) M. Kaji, ACS Symposium Series, 579, 220 (1994)

11) M. Kaji, K. Ogami, and T. Endo, J. Appl. Polym. Sci., 72, 953 (1999)

12) M. Kaji, K. Nakahara, K. Ogami, and T. Endo, J. Appl. Polym. Sci., 75, 528 (1999)

13) M. Kaji, K. Nakahara, and T. Endo, J. Appl. Polym. Sci., 74, 690 (1999)

14) M. Kaji, K. Nakahara, K. Ogami, and T. Endo, J. Polym. Sci. Part A: Polym. Chem., 37, 3687 (1999)

15) S. Takayama et al., Polymer preprints Japan, 43(7), 2141 (1994) 